Rochester Institute of Technology

RIT Scholar Works

$6-22-2020$

\title{
Phase One Research Results from a Project on Vertical Transfer Students in Engineering and Engineering Technology
}

\author{
Surendra K. Gupta \\ Rochester Institute of Technology \\ Franz Allen Foltz \\ Rochester Institute of Technology \\ James E. Moon \\ Rochester Institute of Technology \\ Roy W. Melton \\ Rochester Institute of Technology \\ Michael E. Kuhl \\ Rochester Institute of Technology
}

See next page for additional authors

Follow this and additional works at: https://scholarworks.rit.edu/other

\section{Recommended Citation}

Gupta, S. K., \& Foltz, F. A., \& Moon, J. E., \& Melton, R. W., \& Kuhl, M. E., \& Valentine, M. S., \& Lee, J. H., \& Garrick, R., \& Liu, R. (2020, June), Phase One Research Results from a Project on Vertical Transfer Students in Engineering and Engineering Technology Paper presented at 2020 ASEE Virtual Annual Conference Content Access, Virtual On line . 10.18260/1-2--35053

This Conference Paper is brought to you for free and open access by the Faculty \& Staff Scholarship at RIT Scholar Works. It has been accepted for inclusion in Presentations and other scholarship by an authorized administrator of RIT Scholar Works. For more information, please contact ritscholarworks@rit.edu. 
Authors

Surendra K. Gupta, Franz Allen Foltz, James E. Moon, Roy W. Melton, Michael E. Kuhl, Maureen S. Valentine, James H. Lee, Robert D. Garrick, and Ren Liu 


\section{Phase One Research Results from a Project on Vertical Transfer Students in Engineering and Engineering Technology}

\section{Dr. Surendra "Vinnie" K. Gupta, Rochester Institute of Technology (COE)}

"Vinnie" Gupta is a professor of mechanical engineering, and a member of the graduate faculty of materials science and engineering at the Rochester Institute of Technology (RIT), Rochester, NY. He is a recipient of the 2014 Robert G. Quinn Award from ASEE, and the 2000 Eisenhart Award for Outstanding Teaching. At RIT, he teaches undergraduate and graduate courses in applied mechanics, computational techniques, and materials science.

\section{Prof. Franz Allen Foltz, RIT}

Franz Foltz is an associate professor with dual appointments in the Departments of Science, Technology and Society and Public Policy at the Rochester Institute of Technology (RIT), Rochester, NY. He is the Director of the Graduate Program in Science, Technology and Public Policy. At RIT, he teaches undergraduate and graduate courses in Science and Technology Policy, Research Design, and Policy Analysis.

\section{Dr. James E Moon, Rochester Institute of Technology (COE)}

James Moon, Rochester Institute of Technology James Moon is a Professor in the Electrical and Microelectronic Engineering department. He was a recipient of the 2009 Eisenhart Award for Excellence in Teaching. At RIT, he teaches undergraduate and graduate courses primarily in semiconductor device physics, solid-state physics, and electronics.

\section{Dr. Roy W Melton, Rochester Institute of Technology (COE)}

Roy Melton is Interim Associate Department Head and Principal Lecturer in the Department of Computer Engineering of the Kate Gleason College of Engineering (KGCOE) at the Rochester Institute of Technology (RIT) in Rochester, N.Y. His awards and honors include KGCOE Award for Exemplary Performance in Teaching (2017 and 2014), selection as "most effective teacher" by RIT Computer Engineering classes of 2017, 2015, 2013, 2012, 2011, and 2010, and finalist for the 2015-2016 and 2012-2013 RIT Outstanding Teaching Award for Non-Tenure-Track Faculty. He received his Ph.D., M.S.E.E., and B.E.E. degrees from the Georgia Institute of Technology in Atlanta, Ga. His memberships include ASEE and IEEE (Senior Member).

\section{Dr. Michael E. Kuhl, Rochester Institute of Technology (COE)}

Michael E. Kuhl, $\mathrm{PhD}$ is a Professor in the Department of Industrial and Systems Engineering at Rochester Institute of Technology. He earned his PhD in Industrial Engineering in 1997 from North Carolina State University. His research and teaching interests are in simulation, operations research, and decision analysis with a wide range of application areas including autonomous material handling, healthcare systems, project management, cyber security, and supply chain systems.

\section{Prof. Maureen S. Valentine, Rochester Institute of Technology (CET)}

Maureen Valentine, P.E., is currently a Professor, graduate coordinator and department chair for the Department of Civil Engineering Technology, Environmental Management and Safety at RIT. She has been a faculty member at RIT for more than 26 years and has held various positions including instructional faculty, Associate Dean of the College and co-PI on the AdvanceRIT initiative. Her scholarly activities recently have focused on women in technology programs and the female faculty who teach them.

\section{Dr. James H. Lee, Rochester Institute of Technology (CET)}

James H. Lee is an associate professor at the Rochester Institute of Technology. His areas of research expertise include internal combustion engines, renewable fuels, the design and implementation of sustainable energy systems, and technical and economic analysis of system upgrades to improve energy efficiency. Dr. Lee is a professional engineer licensed in the state of New York. 
Dr. Rob Garrick, Rochester Institute of Technology (CET)

Robert D. Garrick, Ph.D., P.E., is a Professor in the Department of Manufacturing and Mechanical Engineering Technology at the Rochester Institute of Technology (RIT) and Department Chair. Garrick worked for 25 years in automotive engineering research and holds seven U.S. patents.

Mr. Ren Liu 


\section{Phase One Research Results from a Project on Vertical Transfer Students in Engineering and Engineering Technology}

This paper reports on the first phase of research on a scholarship program VTAB (Vertical Transfers' Access to the Baccalaureate) funded by a five-year grant from the National Science Foundation (NSF) that focuses on students who transfer at the $3^{\text {rd }}$ year level from 2-year schools to the engineering and engineering technology BS programs at our university [1]. The goals of the program are: (i) to expand and diversify the engineering/technology workforce of the future, (ii) to develop linkages and articulations with 2-year schools and their S-STEM programs, (iii) to recruit, retain, and graduate 78 low-income students, and place them in industry or graduate schools, (iv) to generate knowledge about the program elements that can help other universities, and (v) to serve as a model for other universities to provide vertical transfer students access to the baccalaureate degree.

VTAB uses lessons learned from an earlier TiPi (Transfer Pipeline) project to achieve the first three goals [2]. The fourth goal is addressed through the use of online surveys and focus group interviews conducted by an outside evaluator. The TiPi project began in June 2012 funded by a four-year grant of $\$ 599,984$ from NSF. It provided scholarship support of $\$ 8,000$ to 75 students who transferred from a 2-year school to a BS degree program in engineering or engineering technology at our university. Of the 75 TiPi scholars, only 4 (5\%) left our university, and the remaining 71 (95\%) graduated with at least a BS degree.

The VTAB program is in its fourth year. Its goal was to recruit 26 low-income transfer students from 2-year schools in three yearly cohorts for a total of 78 scholars. Figure 1 shows each year's recruitment goal, and the resulting cohort size. The project has met its goal of recruiting 78 scholars.

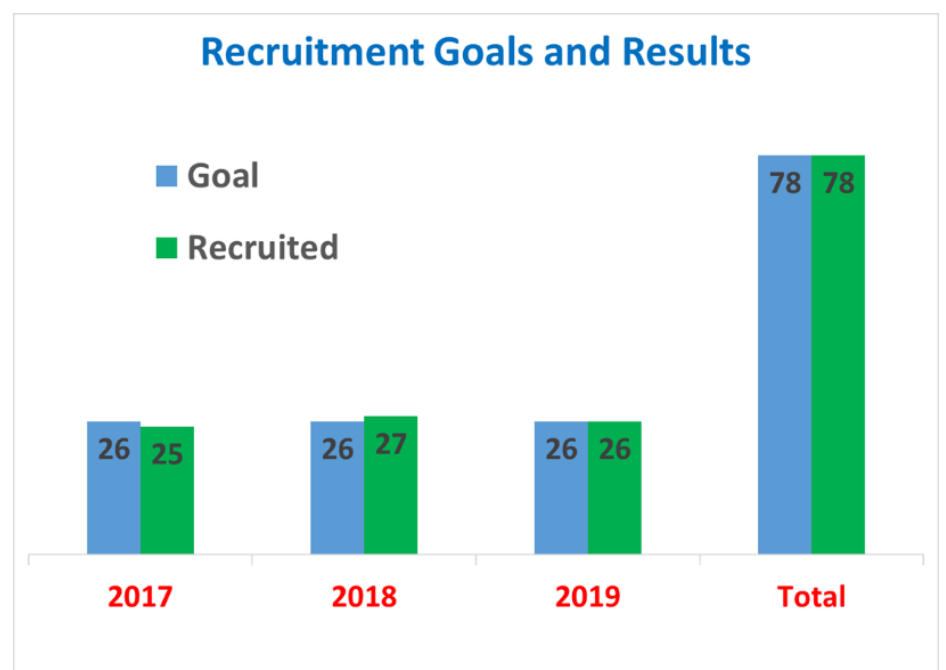

Figure 1: Number of transfer students recruited from 2year schools in Fall of 2017, 2018, and 2019

The VTAB project is a collaborative effort of eight academic departments from two colleges Engineering and Engineering Technology, the Enrollment Management and Career Services 
Division, and the Office of Financial Aid and Scholarships. Collectively, these eight departments offer thirteen BS degree programs that are five-year programs with a mandatory cooperative education component wherein students attend classes in Fall and Spring semesters in their first two years. During the third and fourth years, students alternate between on-campus study and off-campus co-op employment in industry. All students must complete at least 48 weeks of paid co-op employment. Each student finds co-op employment with help from an assigned co-op coordinator in the Office of Cooperative Education and Career Services [2].

Each scholar will receive a scholarship of $\$ 2,500$ per semester for four semesters for a total of $\$ 10,000$. This scholarship is in addition to other grants and aid consistently awarded by our university. After the grant expires, our university will ensure that continuing VTAB scholars have adequate financial support to complete their degree.

Our goal based on the TiPi project is to retain and graduate at least $95 \%$ of these scholars. Figure 2 shows the retention statistics in each academic term beginning the Fall of 2017. The five bars for each term indicate the number of scholars (i) on campus, (ii) on co-op employment, (iii) on official leave of absence, (iv) graduated, and (v) left our university. One scholar graduated at the end of the Summer of 2019. Only one scholar left our university resulting in $98 \%$ retention so far.

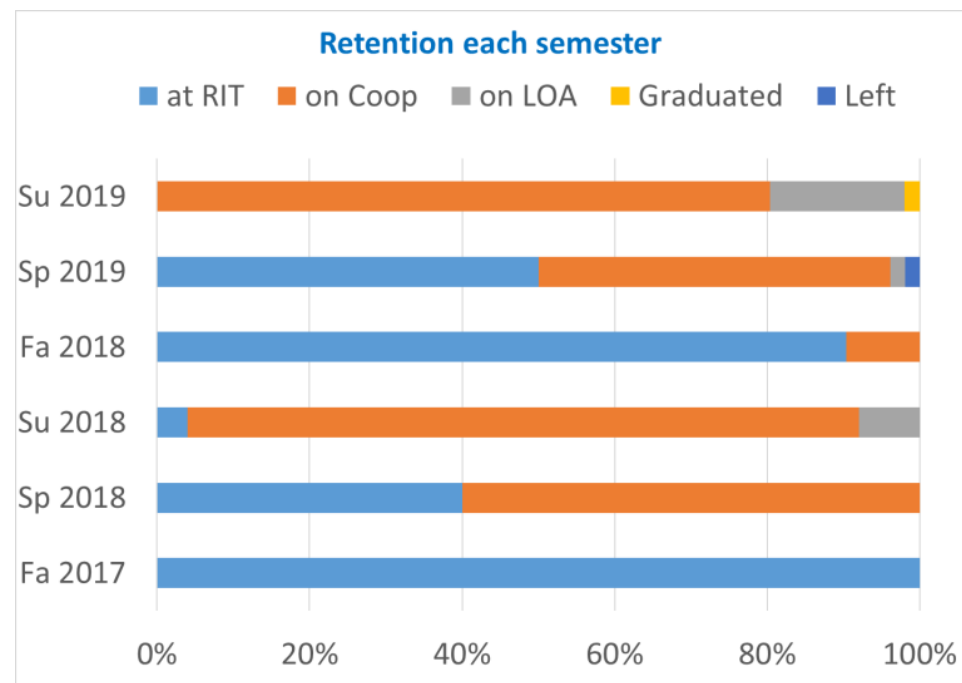

Figure 2: Number of scholars (i) on campus, (ii) on co-op, (iii) on leave of absence, (iv) graduated, and (v) left our university in each academic term beginning the Fall of 2017

In order to better understand the needs of the scholars, each cohort will be surveyed three times during their three years at our university. The first phase addresses the scholars' experiences with transferring into the program, summarizes their experiences at their 2-year school, and explores their preconceptions of what life will be like at our university through both a survey and a focus group during their first semester on campus. The second phase, administered after 3 semesters in the program, uses just a survey to examine what issues the students have been having, how the orientation activities have helped them succeed at our university, and how their 
preconceptions have changed. The final phase using both a survey and focus group, administered just before graduation, addresses which aspects of the program were useful, and where improvements can be made.

This paper addresses the first phase of the research conducted on the VTAB program since all three cohorts have now been surveyed. It will describe the two research instruments: the online survey included in the appendix, and a focus group interview that we developed and administered to the transfer scholars in their first year.

Literature Review: A number of studies examining students that transferred from 2-year to 4year institutions helped to focus our research.

A 2015 study [3] utilized a comprehensive longitudinal dataset containing a census of every public high school student in the state of Florida to conclude that (i) 2-year college transfer students are sensitive to distance often choosing the nearest 4-year institution; (ii) if the nearest 4-year institution is far away, students do not transfer at all; and (iii) low-income students often transfer to the nearest 4-year institution despite the fact that it may have fewer resources and low graduation rates. So, a 4-year private institution must cast a wider net - say contact all 2-year colleges in a 300 mile radius (a day trip by car), and must find novel ways to reach potential transfer students and their families.

Using data from the National Student Clearinghouse study of more than 700,000 degree-seeking students, the Community College Research Center at Columbia University recently reported [4] that transfer students at very selective 4-year institutions had higher graduation rates than all other institutions $-52 \%$ for low-income versus $60 \%$ for high-income students. The report asks the state policymakers to encourage the very selective institutions to enroll more transfer students from 2-year colleges. At our university, the graduation rate of vertical transfers is about $77 \%$, and was $95 \%$ for vertical transfers in the NSF supported TiPi program mentioned earlier [2].

From 2007 to 2010, the Jack Kent Cooke Foundation (JKCF) funded eight highly selective 4year institutions to enroll 1,100 high-achieving low-income to moderate-income transfer students [5]. 97\% of these Cooke Transfer Scholars earned their baccalaureate degree in three years [6]. These scholars were selected from a pool into which each 2-year college nominated its best two students which might explain the $97 \%$ success rate. Nevertheless, there are proven strategies to increase graduation rates among vertical transfers.

By following 111 high-achieving low-income transfer students in the JKCF program, a recent research study [7] identified challenges faced by these students, and classified them into four broad categories: (i) Academic (managing academic load, obtaining good grades, being a strong student); (ii) Social (fitting in and making friends, finding a study group, finding suitable extracurricular activities); (iii) Financial (paying for school and living expenses); and (iv) Personal (leaving family and home community, mental or physical health). Thus, a vertical transfer program must address these four issues to be successful [8-11]. 
Online Survey \#1 and Focus Group Interview: We designed a 28-question online survey with free comment space adapting some of the questions from past surveys [5, 12-14]. The survey was organized to examine the participants' experiences at their 2-year schools, and their experiences during the transfer process, as well as their experiences while enrolling at our university. In particular, it examines the four types of challenges that were addressed in the VTAB orientation course. 23 out of 25 scholars from the first cohort (2017), 23 out of 27 scholars from the second cohort (2018), and all 26 scholars in the third cohort (2019) responded to the survey. Additional surveys will be administered throughout the scholars' experience that will build on this first survey, and provide a complete picture of their experience in the VTAB project.

Our outside evaluator then drew on the survey results to construct a series of focus group questions. He and/or one of his graduate students conducted a focus group with a volunteer group from each of the three cohorts. The focus groups tried to expand on the students' survey responses, and provide more detail on their experiences transferring to and starting at our university. The outside evaluator sent us transcripts for each of the three focus groups, which were used for this paper.

Because reporting on all 28 survey questions and the three focus groups would require considerable amount of space, we will only report on the more interesting results below. The other answers were as we expected.

The first section of the survey asked for basic demographic information. 64 scholars are male, and 14 are female. Under NSF classification for race, 58 reported White, 10 Asian, 4 black or African American, and remaining 6 did not answer. The demographics of VTAB scholars in gender, ethnicity, and family is similar to that of our university. VTAB scholarship is based solely on financial need and academic merit.

Before Enrolling at our university: The second section of the survey examined the student's experiences at their various 2-year schools. From question \#4, the most striking if not predictable finding was that the majority of all three cohorts attended a 2-year school due to financial reasons. Figure 3 shows the $\%$ of scholars in each cohort citing financial reasons for attending a 2-year school instead of a 4-year institution. 


\section{$\%$ of Scholars citing Financial Reasons to attend a 2-year school}

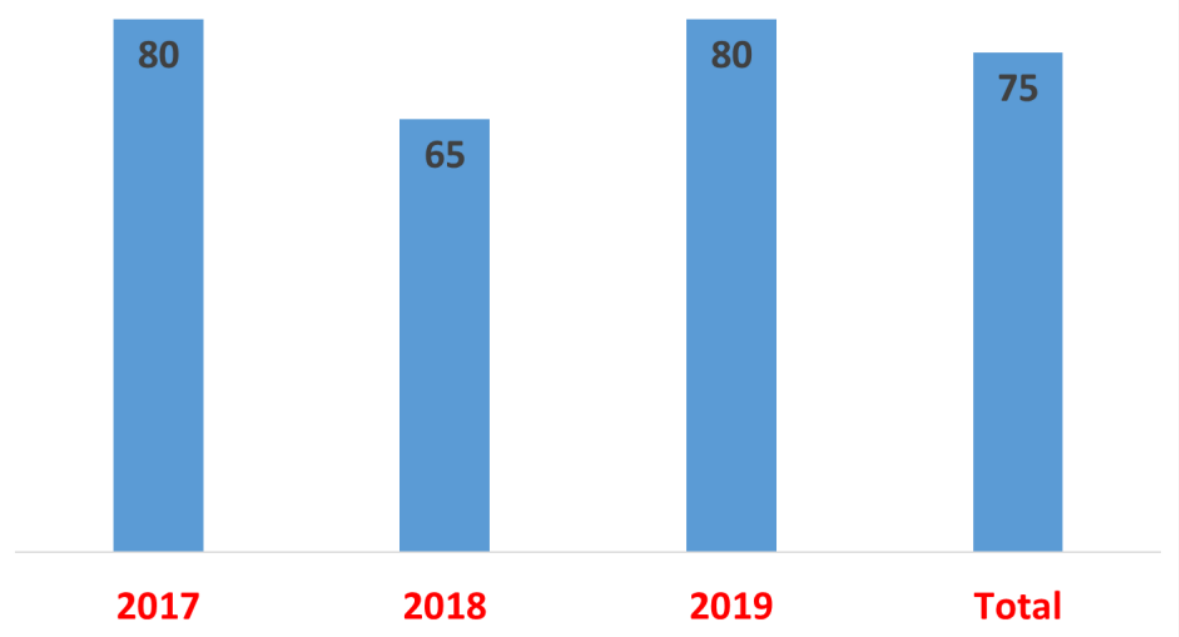

Figure 3: Percentage of Scholars in each cohort citing financial reasons to attend 2-year school instead of a 4-year school. Question \#4.

Responses to question \#6 show that most scholars (over $90 \%$ of each cohort) always planned on transferring to a 4-year institution afterwards. Figure 4 show $\%$ of scholars in each cohort who had planned to transfer to a 4-year institution.

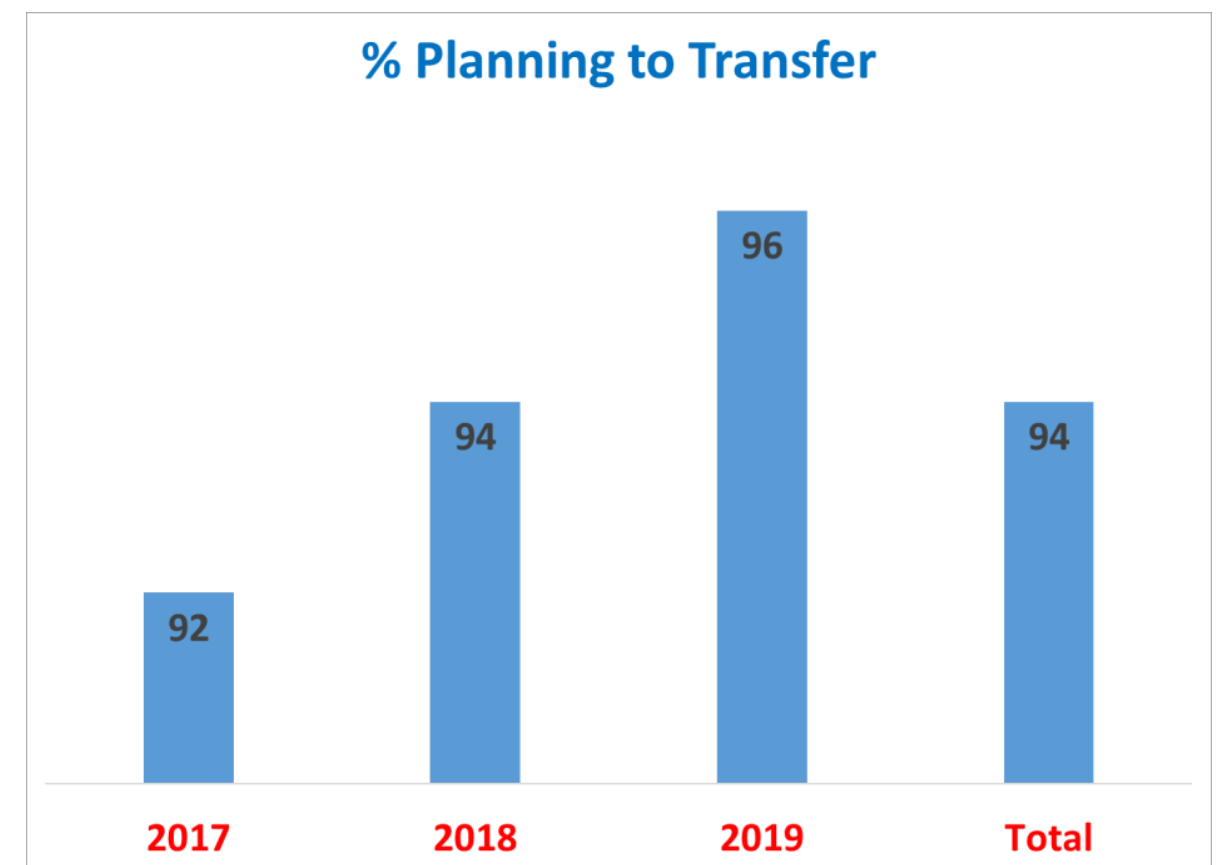

Figure 4: Percentage of scholars in each cohort responding that they had planned to transfer to a 4-year institution. Question \#6. 
For low-income students, beginning at a 2-year school and then transferring to a 4-year institution reduces the total cost of getting a high quality engineering or engineering technology BS degree. In New York State, many students would be able to attend a 2-year school for free, which would reduce their cost by 50\%. The National Science Foundation [15] found that the primary reason that individuals attended 2-year schools was financial. The Purdue-Gallup Study [16] also supports this finding.

The survey has a series of questions regarding personal, resource, academic and social issues. The data presented is for the entire group as each cohort's results were fairly similar (there were no significant differences between the cohorts). The data is presented in total count, and not percentages because not all students answered all of the questions. In a later question, students will be asked what their expectations of their 4-year college experience will be.

Generally, students did not have a lot of personal issues at their 2-year schools as shown by the large amount of blue in Figure 5 in response to question \#11.

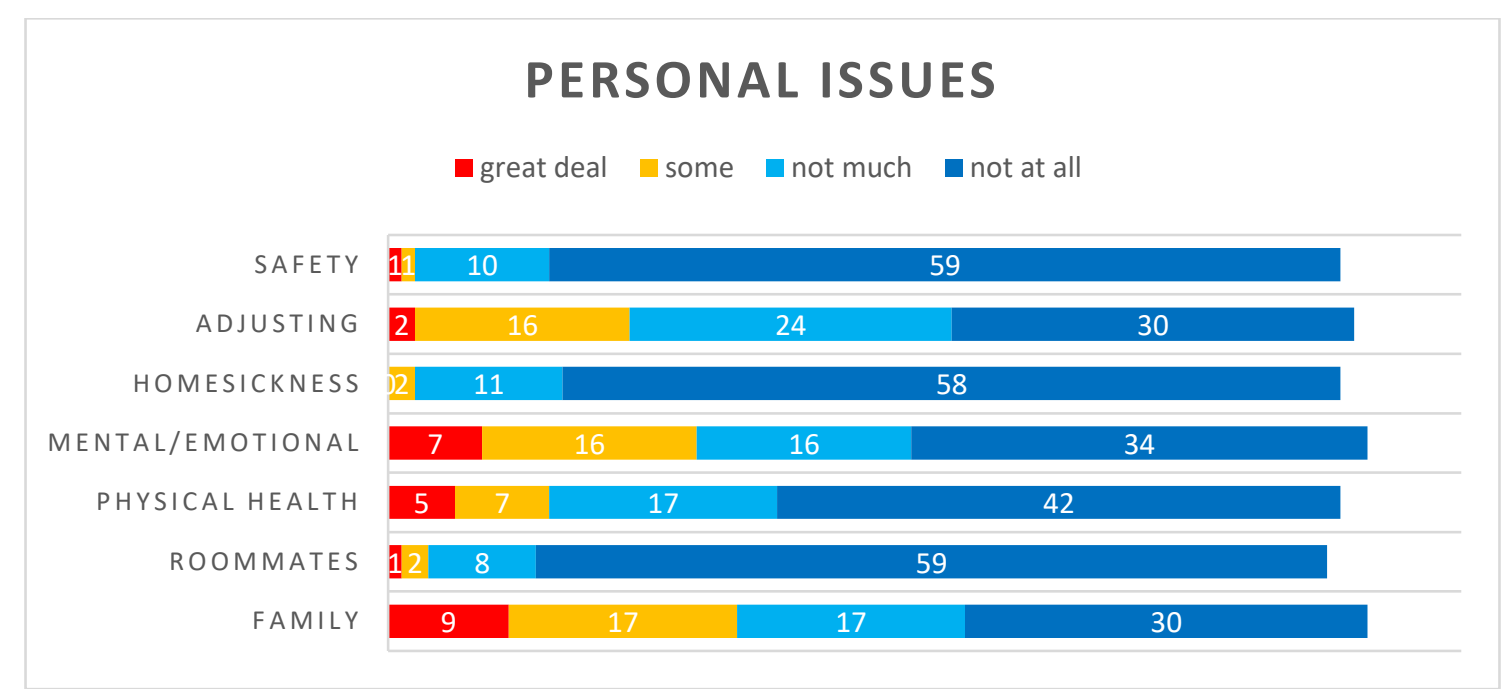

Figure 5: How challenging were each of these Personal Issues at your 2-year school? Question \#11.

Figure 6 shows responses to question \#12 regarding resource issues. 


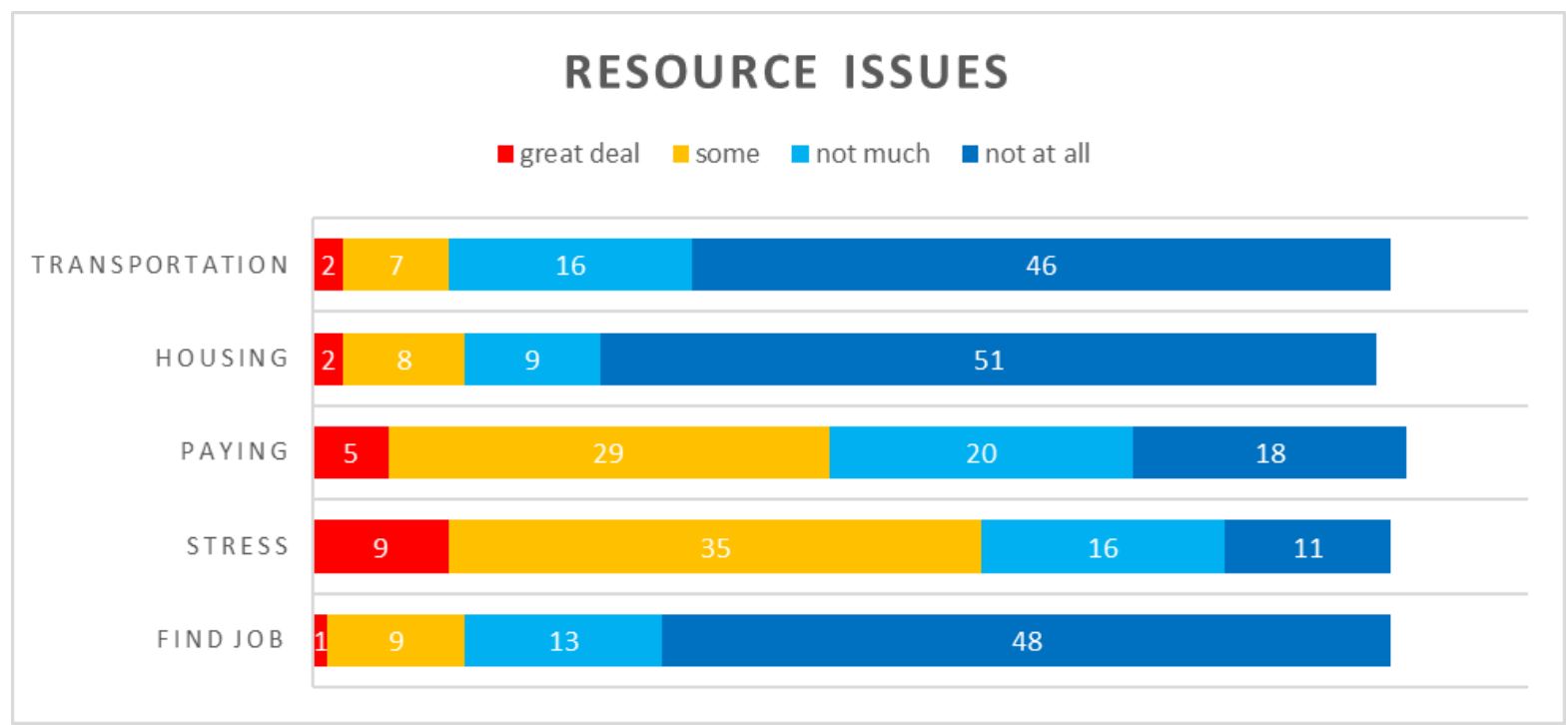

Figure 6: How challenging were each of these Resource Issues? Question \#12.

Some scholars reported experiencing stress and having concern about paying bills as seen by the amount of yellow and red in those categories. Both are related and are logical issues for low income students, which supports existing research. They did not have significant issues concerning finding jobs, housing or transportation, which might again be connected to living close to home. This connects to the Gallop-Purdue Study [16] which found that student debt was a major issue with all college age students, which impacts their life during and after college.

Figure 7 shows responses to question \#13 regarding academic issues. Their biggest issue at their 2-year schools seemed to be in the academics, followed by keeping up with their work and reading, their papers and projects, and maintaining their focus. Dealing with advising and faculty were significantly less problematic. So, it appears that 2-year schools have wellfunctioning advising system, and supportive faculty.

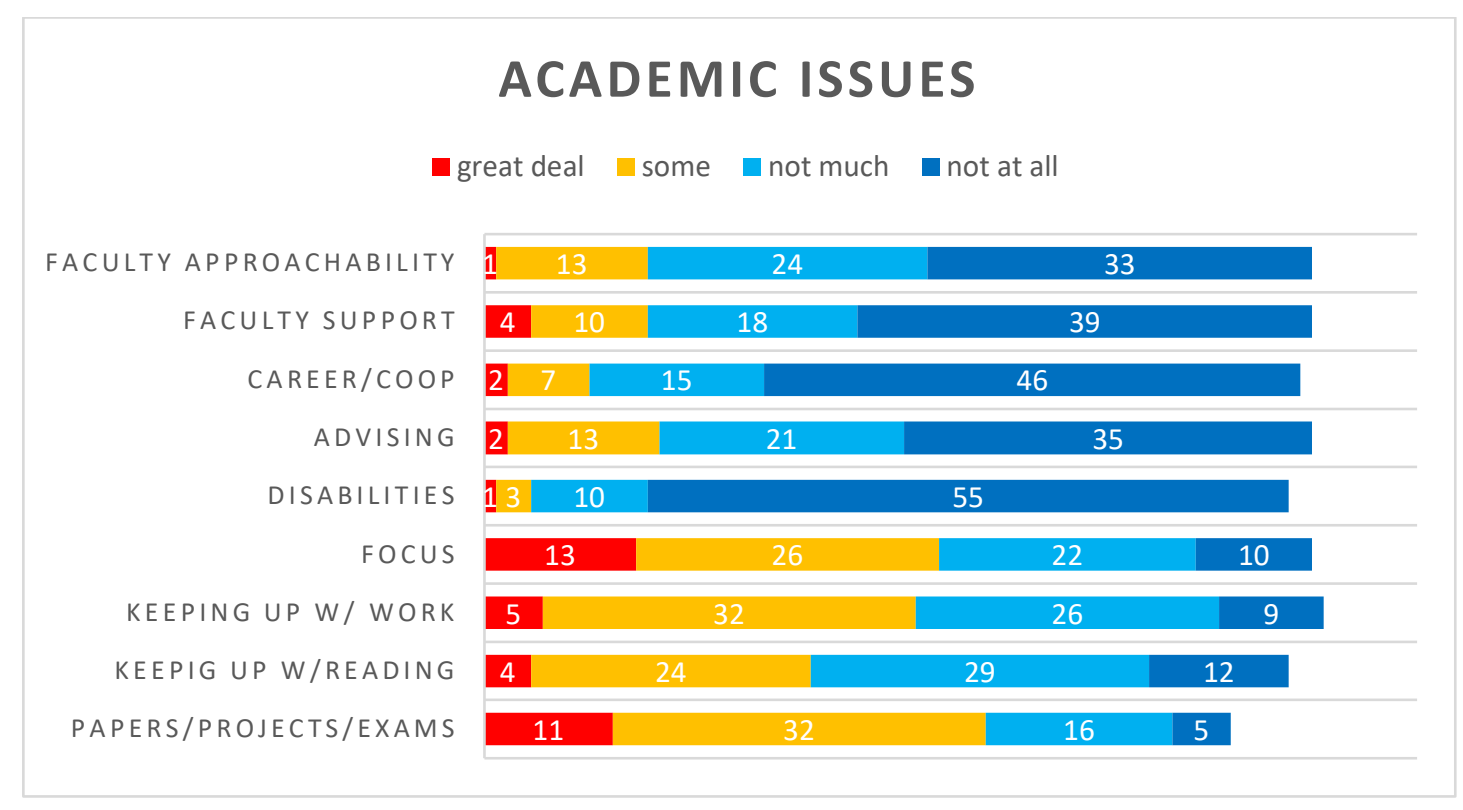


Figure 7: How challenging were each of these Academic Issues? Question \#13.

Figure 8 shows that the biggest concern reported was keeping a good balance between work and social life. More than half had at least some challenges maintaining a good balance. Only a minority reported having significant social concerns. Since most of them were attending 2-year schools close to home, their social life should have been fairly stable from their high school days.

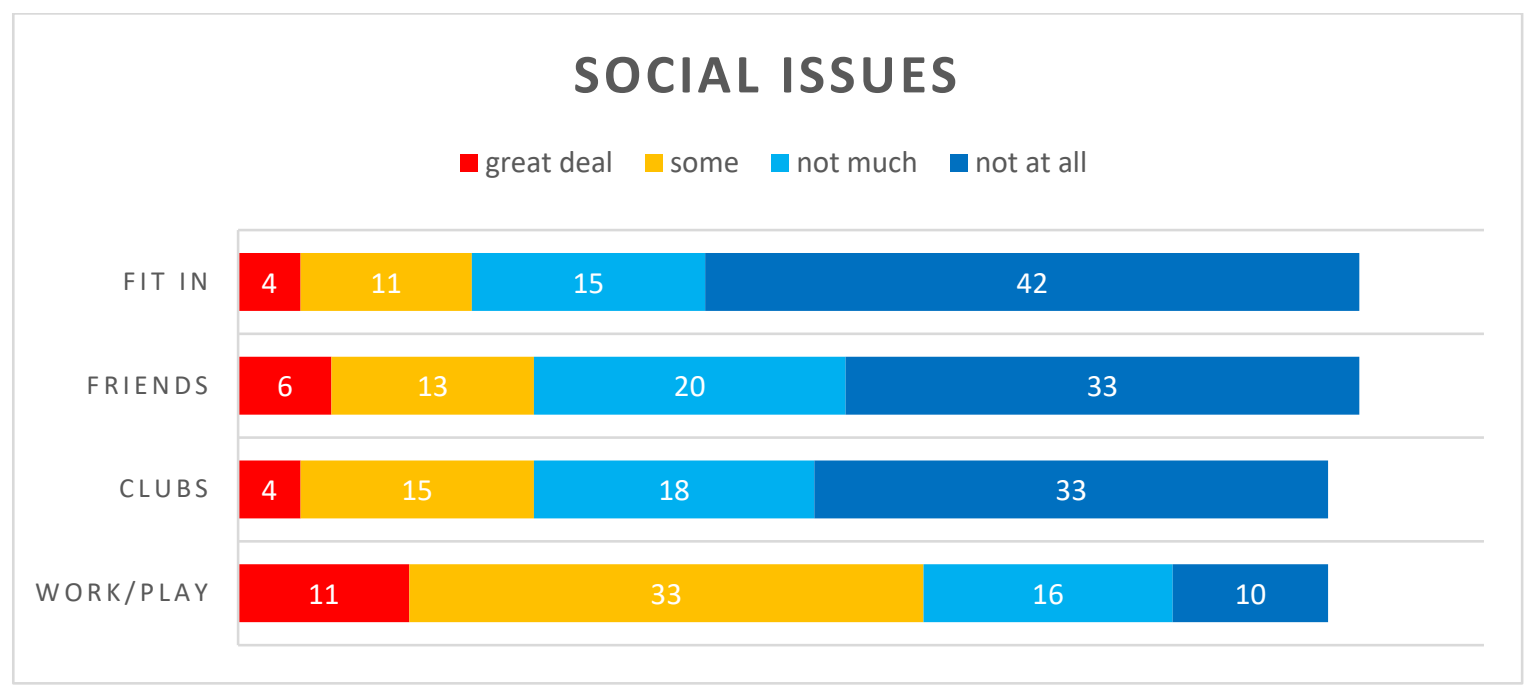

Figure 8: How challenging were each of these Social Issues? Question \#14.

Overall, the survey found low-income students had money-related issues, and some academic ones. However, in most social and personal areas, they had few issues.

Transferring to our university: The third section of the survey addressed the transferring process. Overall, scholars were pleased with the transfer process. Our university has been accepting transfer students from 2-year schools for a long time, so the transfer process is now quite smooth. The nature of the relationship between our university and the 2-year school made the process easier for many of students as the following statement from one of the focus groups confirmed.

I know that there was two plus two, so that if I get accepted at the program at MCC that I will automatically get transferred, everything will be transferred over smoothly to our university. There was the transfer process wasn't very difficult.

Figure 9 shows how many scholars took advantage of events at our university to facilitate the transfer process. Surprisingly, less than half of the scholars attended either an information session about our university or an open house at our university. Only four out of 72 scholars spent the night at our university. As expected from low income students, many of them explored financial aid information at their school, and from our university specifically. The majority talked with an academic advisor at our university. 


\section{ATTENDING ORIENTATION EVENTS}

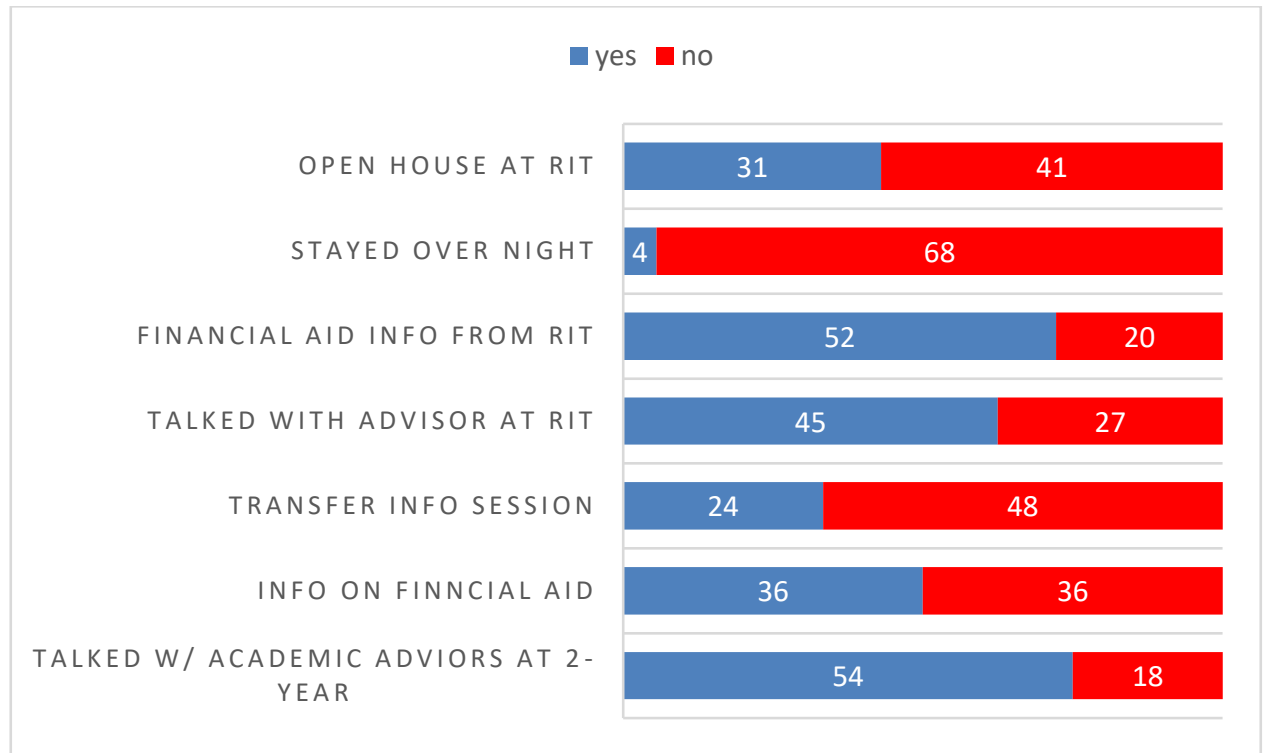

Figure 9: Number of scholars who attended events at our university to facilitate transfer

During the focus group discussions a number of specifics were addressed concerning activities that supported the transfer process. One scholar said:

\{this school\} visited my school, fall semester last year... all college there college of engineer and technology they have a presentation come down and talk about the co-op and study abroad, what you will do with that. The class would be taking, schedule, the housing options. All like that. That's the information I got from them mostly, and then I visited here, did the tour and something like that.

Another student explained how the transfer process was built into their 2-year experience:

Um, there's actually a club at \{my community college\} is the engineering leadership council makes you like planned college trip here it was this for the mechanical department, but just going on economical electrical engineer like being able to see just are around campus just getting a feel what it's like here because we went uh, during the day when classes were happening. So we actually got the kind of see what life was like here before actually applying transfer here. That was helpful.

Figure 10 shows the number of scholars who had admission offers from other 4-year institutions. Most of the scholars were admitted to 4 -year schools in addition to our university. So, they had to make a conscious choice to which 4-year institution that they would attend. 


\section{ADMITTED TO ANOTHER 4-YEAR COLLEGE}

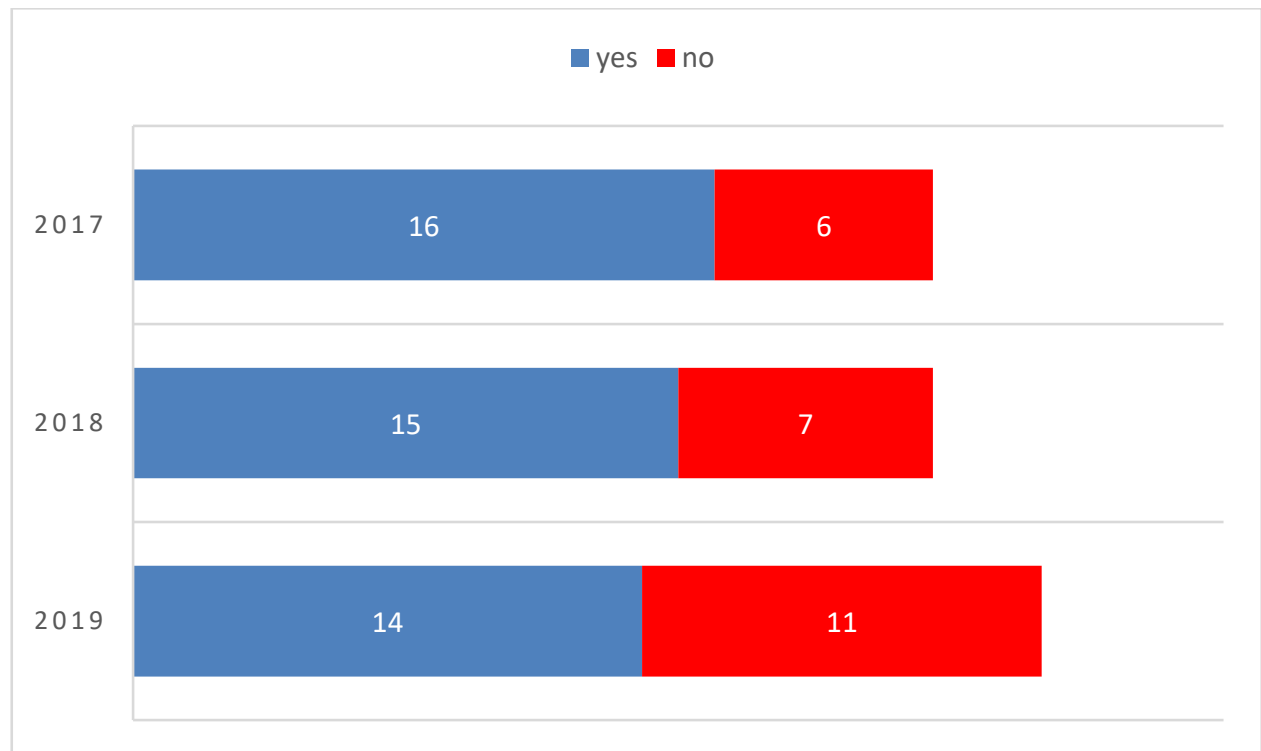

Figure 10: Were you admitted to a 4-year institution other than our university

Figure 11 shows the major reasons why scholars enrolled at our university. For this question, they were asked to check all that applied, so the larger the bar the more students gave that as a reason. Our university's reputation, the choice of majors, mandatory co-op, and the ease of transferring courses were all significant reasons for enrolling at our university. In support of the Florida Study [3], closeness to home was also an important reason for attending our university. Friends and Student housing had much less of an impact.

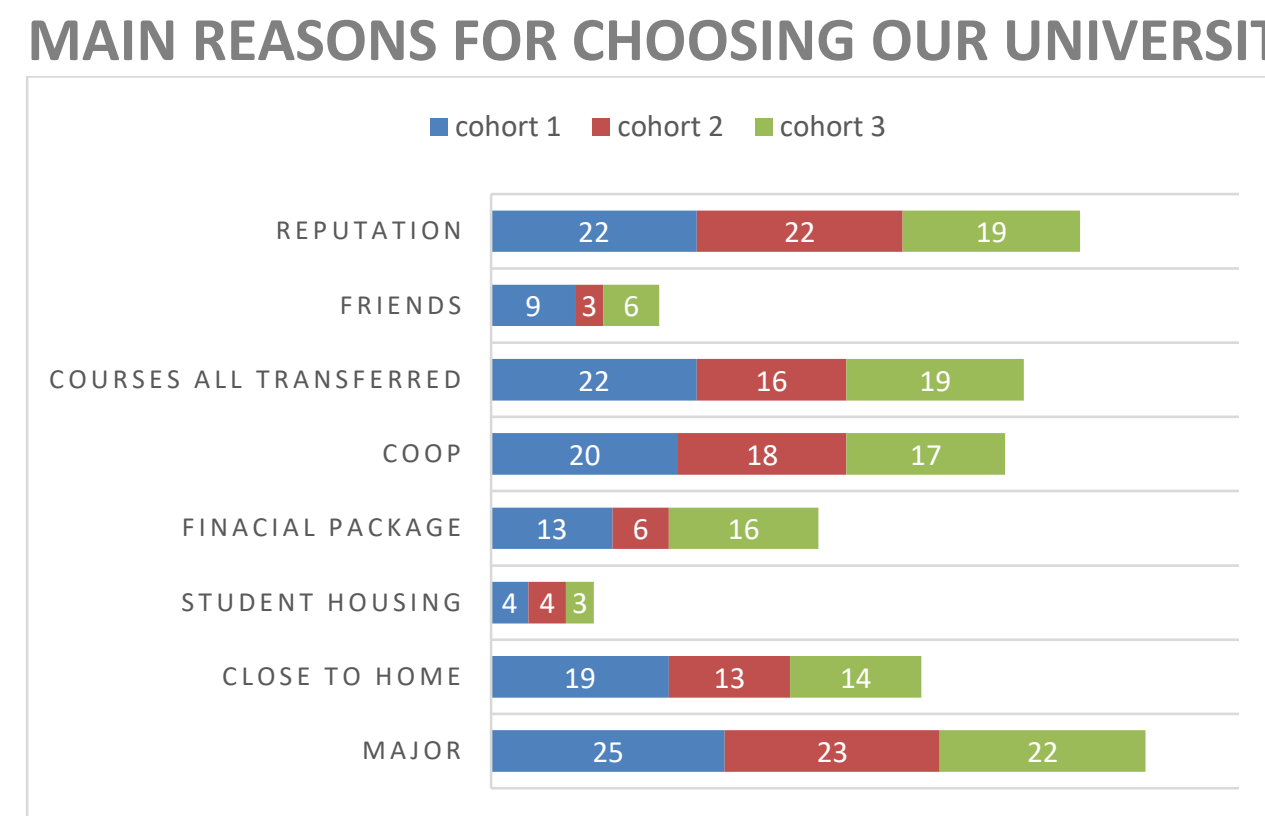

Figure 11: Main reasons for enrolling at our university 
Even though the closeness to home was fifth in the survey, it was the first issue that a number of students brought it up during the focus group discussions. The first student began the discussion of why they chose our university. It was:

Close to home. \{this school\} is in \{this city\}, there so \{this school\} was only five minutes away from community college. I don't need to change my living situation.

Another added:

\{This school\} is really close to home. It was like twenty minutes away from the community I live. And another thing is the co-op program. It's just too good to pass up. Close to home.

The second reason that was discussed at the focus group was the Co-op focus. One student argued:

So, so, I chose \{this school\} cause the co-ops, um, I got a scholarship I didn't expect I was gonna get, and honestly was between (state university) and \{this school\}. (state university) being, you know, the less expensive school, but they also didn't have that mandatory co-op program. And I figured that \{this school\} is closer to home would just be easier transition.

Another student agreed:

The job placement after graduation at \{this school\}. The co-ops program.

Enrolling at our university: The final section of the survey dealt with their early experiences at our university, and what their preconceptions were of what life at our university would be like.

Our university offers an option of either a short (half-day) or a long (two-day) orientation program to all the incoming transfer students. To focus on the needs of VTAB scholars, the project administrator created, and taught a zero-credit VTAB Orientation course that met for 50 minutes each week for the first six weeks of the fall semester. In the first five weeks, the course instructor arranged to have local experts conduct workshops focusing on academic integration [8], social integration [9], financial discipline [10], and personal well-being [11]. At the end of the course, we had a Friday social with pizza and cookies, and the external evaluator invited a group of scholars for a focus group interview.

Figure 12 shows that only about half of the students attended at least one of the orientation events on campus. Of those, $75 \%$ found that the events were useful. These findings provide a solid rationale for creating the VTAB Orientation course, since only half took advantage of the university offerings. 


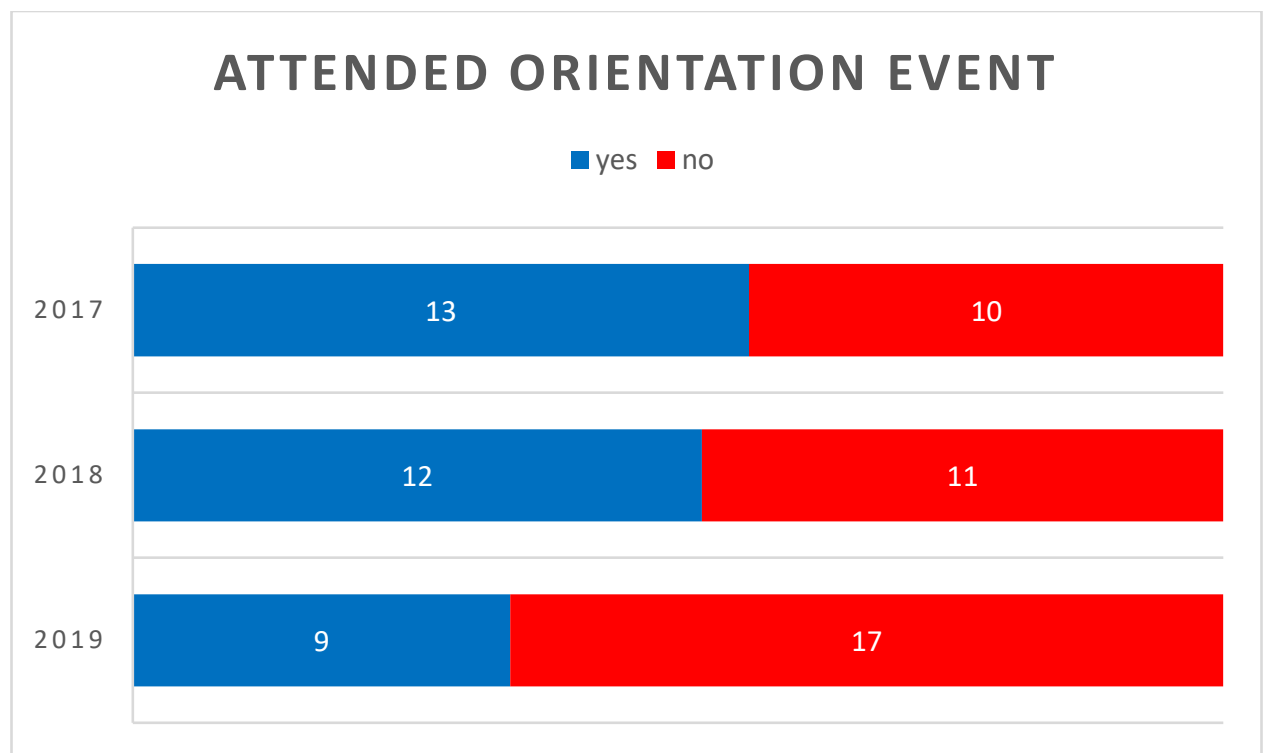

Figure 12: Did you attend any Transfer Orientation events?

Question 28 repeated questions 11-14 which addressed personal, resource, academic, and social issues. This time the question was concerning their expectations of our university instead of the issues at their 2-year school. Universally, the answers were fairly consistent between the two. As one might expect, there is a little more concern at our university but the overall expectations were fairly consistent between their experiences at the 2-year school and their expectations for our university.

Figure 13 shows what each scholar perceived the extent of challenge for each personal issue listed. The results are similar to Figure 5. One interesting observation is that there was no one who thought that safety would be an issue at our university. This might be that they thought the school was safer because it is fairly isolated or that the larger campus would have better protection.

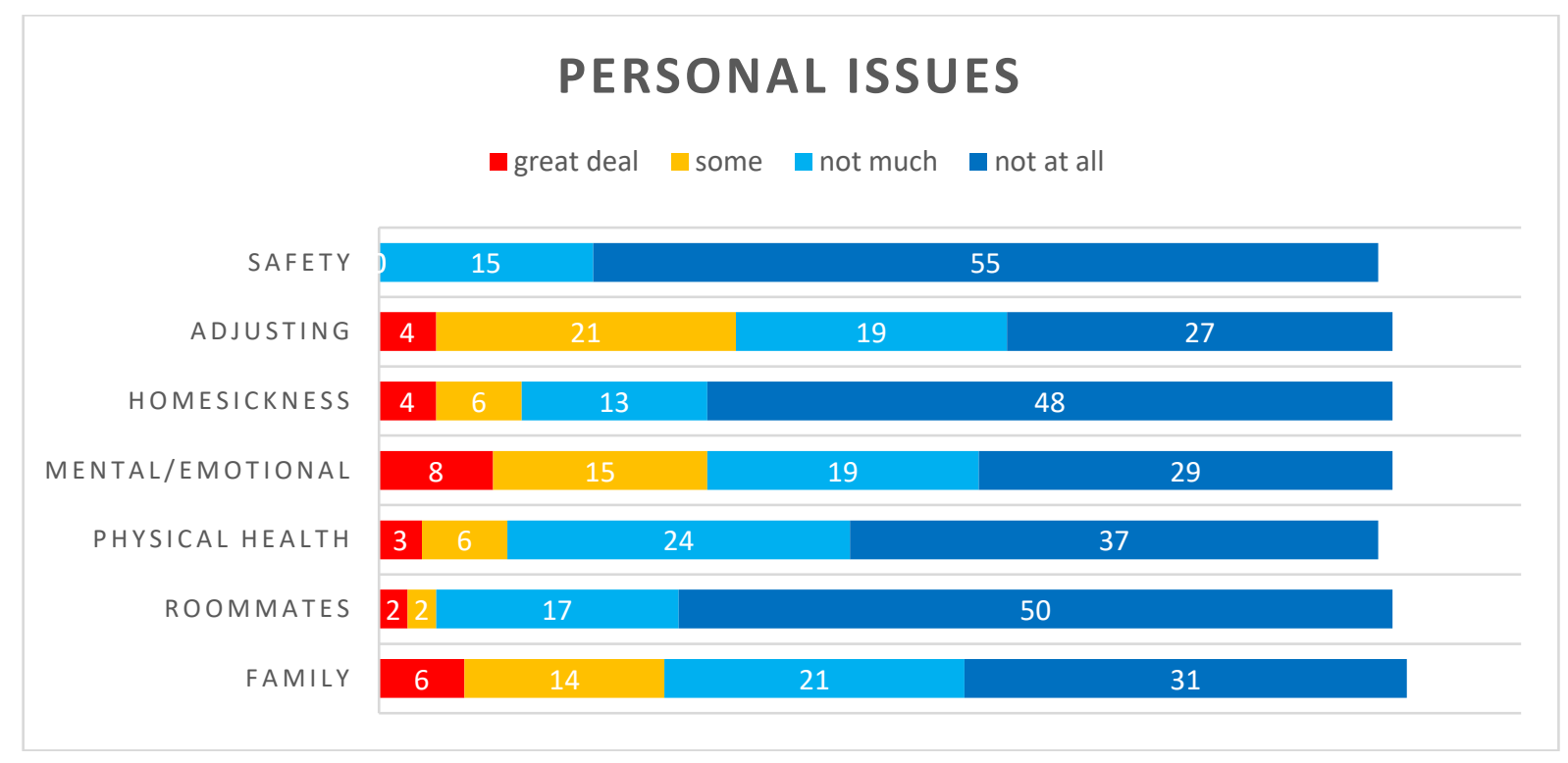


Figure 13: To what extent do you expect Personal Issues to be challenging at our university?

Figure 14 shows that the scholars have the same expectations concerning resource issues that they had with their experience at their 2-year schools. Both might be slightly larger at our university than they were at the 2-year school, but our university would be more expensive and hence would create more stress and concern over money (see Figure 6 in comparison).

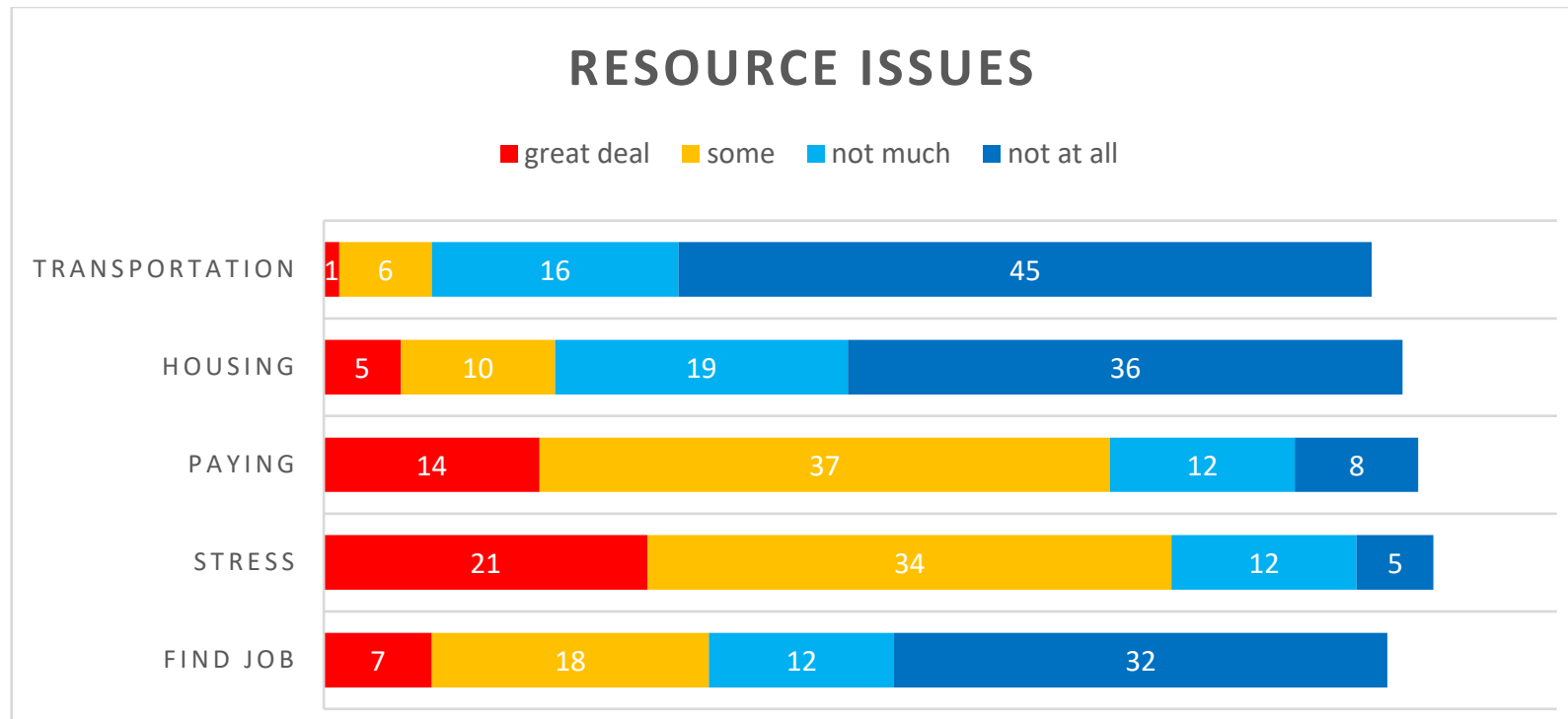

Figure 14: To what extent do you expect Resource Issues to be challenging at our university?

Figure 15 shows that their expectations regarding academic issues were similar to their experience at the 2-year school, though a few more people had concerns over the larger work load (see Figure 7 for comparison). Part of the increased expectations came from the students experiences at our university over the first few weeks. 


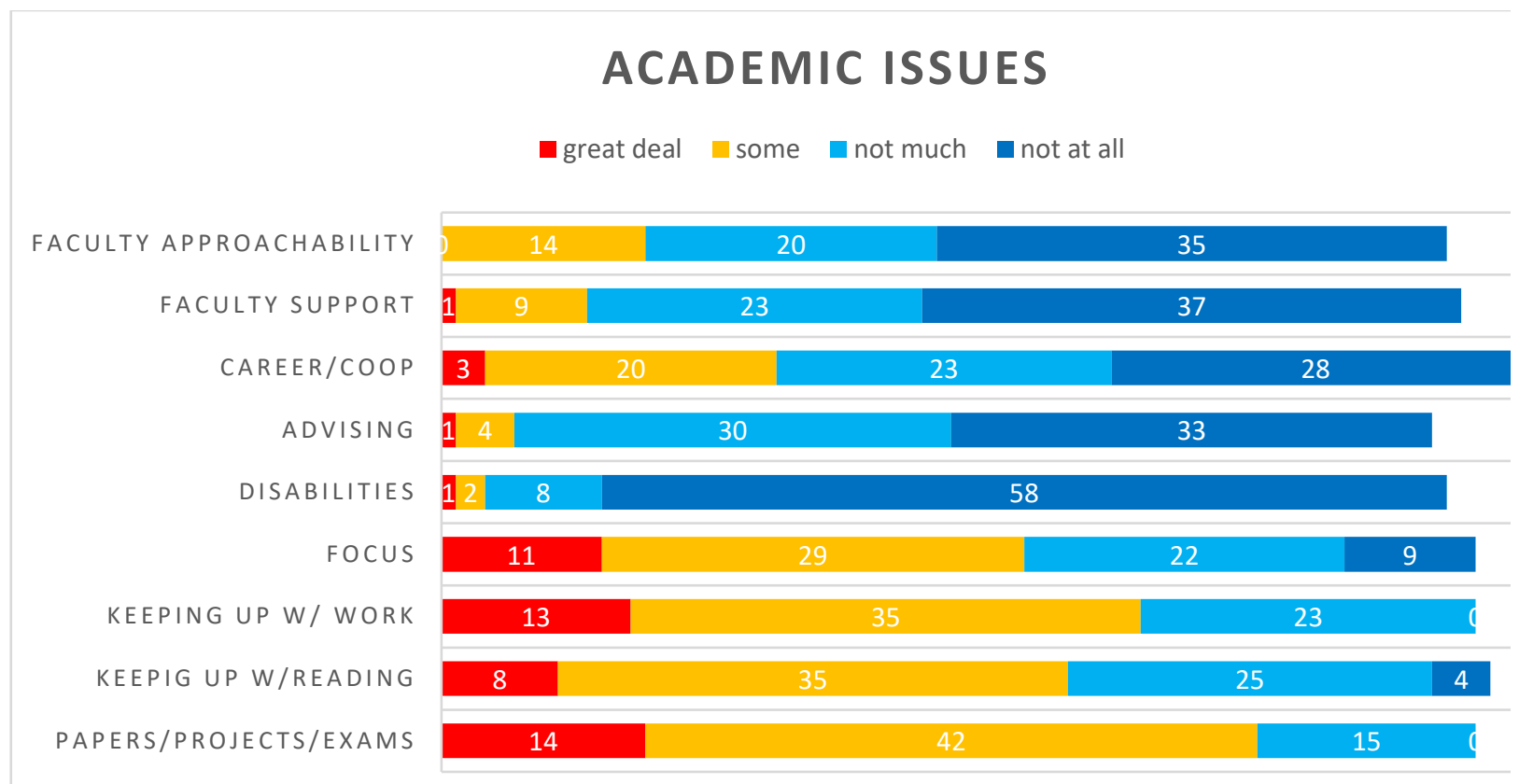

Figure 15: To what extent do you expect Academic Issues to be challenging at our university?

One student made the following statement during the focus groups discussion:

I just think about the amount of homework you get a lot more. But in terms of like the difficulty of the work, I don't think it's I think it's about the same level. I mean, once you get up into the higher courses, a little bit harder, but the amount of homework to get the amount of work is a lot more intense.

Figure 16 shows their responses to social issues. This is very similar to their experiences at their 2-year school (see Figure 8). Over half had some issue with balancing academics with personal and social life.

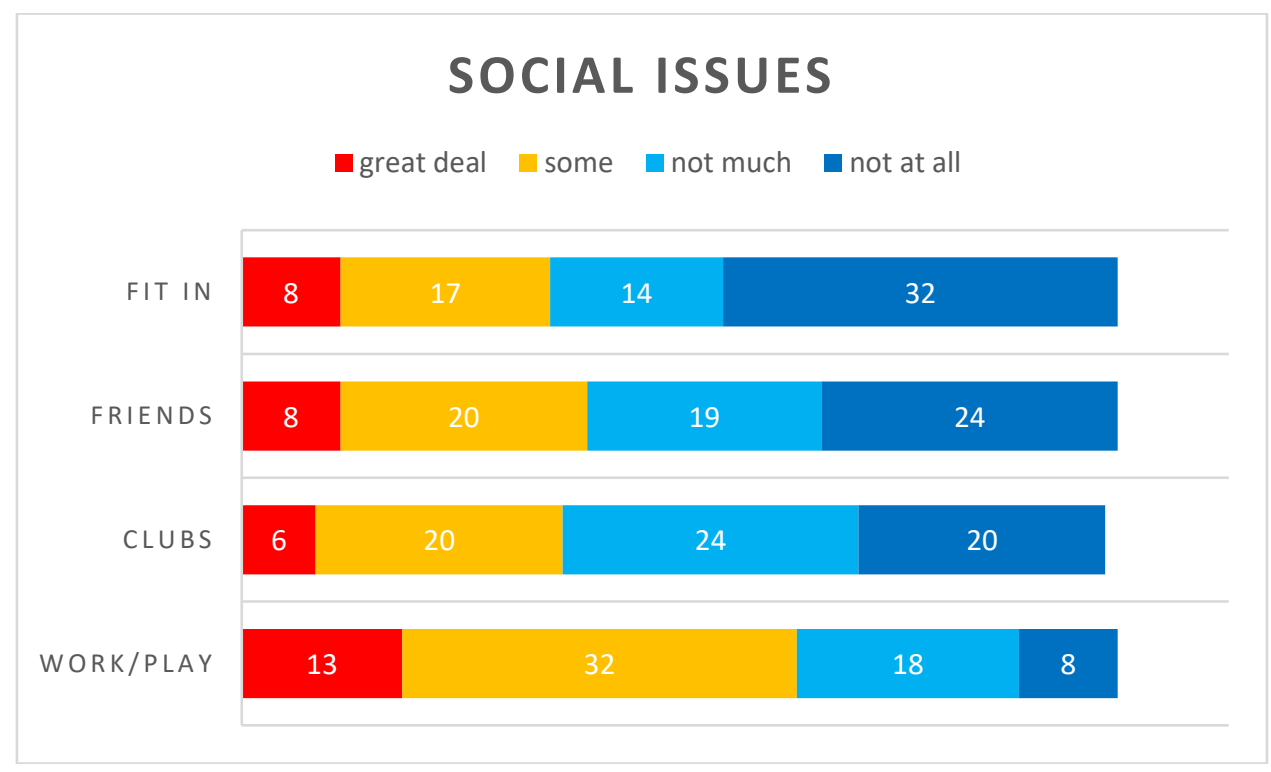


Figure 16: To what extent do you expect Social Issues to be challenging at our university?

Overall, their expectations reflected their earlier experiences with maybe a slightly higher amount of angst being at a bigger, and perceived to be more rigorous school.

Conclusions: Overall, our findings were fairly consistent with existing studies. The students were for the most part concerned with financial aspects of their education. Most chose going to a 2-year school first in order to lower their overall educational costs. They also reported a higher level of concern over financial resource issues than most of the other issues addressed by the survey.

Our findings also supported the idea that proximity to home was important to low-income students in deciding which schools to attend. This suggests that 4-year schools should focus on creating partnerships with 2-year institutions that are near them. This means that there are a limited number of good partners for every school and that the identification and partnering should not be too overwhelming a task.

We also found a number of other useful things. Their expectations for their 4-year schools in most cases mirrors their 2-year experience. We will see how their experiences at the 4-year institution will change. The actual transfer process has been fairly well established, and was fairly easy for the scholars. Finally, that only half of the students took advantage of university wide orientation programs, so the creation of a special orientation course was a very good use of resources for helping students to transition to the 4-year schools. We will see how useful the course was in future surveys.

\section{Acknowledgements}

This work was supported in part by the National Science Foundation under award number DUE1643703. Help from Ms. Deanne Pettinelli in administering the financial aid is gratefully acknowledged.

\section{References}

1. Program Solicitation, "Scholarships in Science, Technology, Engineering, and Mathematics (S-STEM)", NSF 16-540, National Science Foundation, 2016.

2. S. K. Gupta, J. E. Moon, R. W. Melton, M. E. Kuhl, D. P. Johnson, T. Dunn, J. H. Lee, F. Foltz, and R. Garrick, "Scholarship Programs for Vertical Transfers in Engineering and Engineering Technology," Proceedings of the 2018 ASEE Annual Conference in Salt Lake City, UT (June 2018).

3. B. Backes and E. D. Velez, "Who Transfers and Where Do They Go? Community College Students in Florida," National Center for Analysis of Longitudinal Data in Education Research, Working Paper 124, February 2015.

4. D. Jenkins and J. Fink, "Tracking Transfer - New Measures of Institutional and State Effectiveness in Helping Community College Students Attain Bachelor’s Degrees," 
Community College Research Center, Teachers College, Columbia University, January 2016.

5. C. Burack, S. Lanspery, T. P. Shields, and S. Singleton, "Partnerships That Promote Success: Lessons and Findings from the Evaluation of the Jack Kent Cooke Foundation's Community College Transfer Initiative," Brandeis University, MA, January 2014.

6. J. Giancola and E. Davidson, "Breaking Down Walls: Increasing Access to Four-Year Colleges for High-achieving Community College Students," Jack Kent Cooke Foundation, January 2015.

7. B. Schmertz and J. Carney, "Making the Leap: Understanding the Successful Transfer of High-achieving, Low-income Community College Students to Four-Year Institutions," Jack Kent Cooke Foundation, October 2013.

8. https://www.rit.edu/studentaffairs/asc/

9. https://www.rit.edu/studentaffairs/orientation/

10. https://www.rit.edu/studentaffairs/criw/wellness-courses.php

11. https://www.rit.edu/studentaffairs/parent-and-family-programs

12. F. S. Laanan, "Beyond transfer shock: A study of students' college experiences and adjustment processes at UCLA", Doctoral Dissertation, University of California, Los Angeles, CA, 1998.

13. M. T. Peddle and C. E. Trott, "Transfer Student Satisfaction Survey", The Illinois Articulation Initiative, Final Report to the Illinois Board of Higher Education, Center for Governmental Studies, Northern Illinois University, IL, 2016.

14. X. Wang, "Upward Transfer in STEM Fields of Study: A new Conceptual Framework and Survey Instrument for Institutional Research", New Directions for Institutional Research, v170, p49-60, 2016.

15. Gallup and Purdue University, "Great Jobs: The Relationship Between Student Debt, Experience and Perceptions of College Worth," Gallup-Purdue Index 2015 Report, Downloaded from https://www.gallup.com/services/185924/gallup-purdue-index-2015report.aspx?_ga=2.15291839.829636859.1579184871-835021184.1578590164 on January 24, 2020.

16. National Science Board (NSB) Science and Engineering Indicators 2018, National Science Foundation: Washington DC, 2018. 


\section{Appendix Transfer Student Questionnaire}

\section{PART 1: Information about You and Your Family}

1. Gender: Male; Female; Other

2. Ethnicity: White Non-Hispanic; Black Non-Hispanic; Hispanic; Asian American/Pacific Islander; Native American/American Indian; Other (specify); Prefer not to answer; Don’t know

3. Family Income: Independent; Less than $\$ 20 \mathrm{~K} ;<\$ 40 \mathrm{~K} ;<\$ 60 \mathrm{~K} ;<\$ 80 \mathrm{~K} ;<\$ 100 \mathrm{~K} ;<\$ 200 \mathrm{~K}$; More than $\$ 200 \mathrm{~K}$

\section{PART 2: Before Enrolling at our university}

4. What were your main reasons for enrolling in the 2-Year college instead of a 4-Year College or University? (Check all that apply)

For those who did not apply to any 4-Year College or University:

a. I did not apply to 4-Year institution for academic reasons.

b. I did not apply to 4-Year institution for personal reasons.

c. I did not apply to 4-Year institution for financial reasons.

d. I did not apply to 4-Year institution for other reasons.

5. For those who applied to one or more 4-Year Colleges or Universities:

a. I applied to a 4-Year institution but was not accepted

b. I applied to a 4-Year institution but did not enroll for academic reasons.

c. I applied to a 4-Year institution but did not enroll for personal reasons.

d. I applied to a 4-Year institution but did not enroll for financial reasons.

e. I applied to a 4-Year institution but did not enroll for other reasons.

f. I previously attended a 4-Year institution but did not graduate

6. Did you begin attending your 2-Year College with the intention of transferring to a 4-Year College or University?

\section{Yes / No}

7. Did you complete an associate's degree (AA, AS) at your 2-Year College prior to enrolling at our university?

Yes / No

8. How many hours per week did you usually spend at your 2-Year College campus, not counting time attending classes?

$0,<5,<10,<15,<20,>20$

9. How many hours per week did you usually spend studying or preparing for your classes at your 2-Year College, not counting time attending classes?

$0,<5,<10,<15,<20,>20$

10. How many hours per week did you usually spend working on a job for pay?

$$
0,<5,<10,<15,<20,>20
$$

11. In your 2-Year College, to what extent were each of these a challenge to staying in or succeeding in the 2-Year college?

\begin{tabular}{|l|l|l|l|l|}
\hline Challenge & \multicolumn{3}{|l|}{ To what degree is this a challenge? } \\
\cline { 2 - 5 } & $\begin{array}{l}\text { A great } \\
\text { deal }\end{array}$ & Some & Not much & Not at all \\
\hline Personal Issues & & & & \\
\hline Family & & & \\
\hline
\end{tabular}




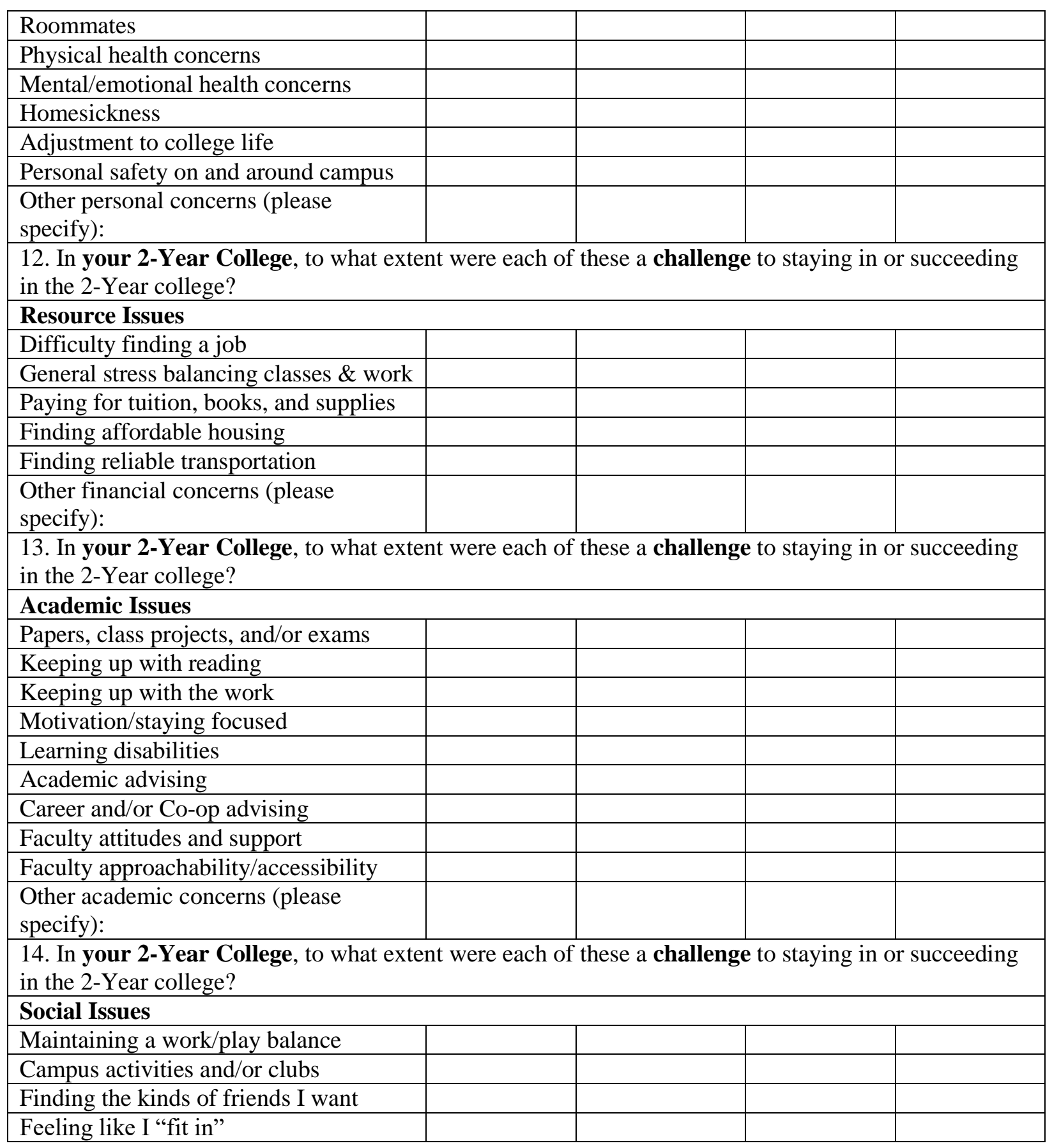

15. To what extent did the following individuals or type of persons help you meet the challenges you faced during the past year while you were in the 2-Year College?

\begin{tabular}{|l|l|l|l|l|l|}
\hline \multirow{2}{*}{ Individual/Type of Persons } & \multicolumn{5}{|l|}{ How much did this person or these persons help you? } \\
\cline { 2 - 6 } & A great deal & Some & Not much & Not at all & Not applicable \\
\hline My academic advisor & & & & & \\
\hline Student Affairs or Services & & & & & \\
\hline Faculty Members /Teaching Assistants & & & & & \\
\hline Club / Extracurricular Advisors & & & & & \\
\hline
\end{tabular}




\begin{tabular}{|l|l|l|l|l|l|}
\hline Peers / Friends & & & & & \\
\hline Family Members & & & & & \\
\hline Boss / Work Supervisor & & & & & \\
\hline Religious Leader & & & & & \\
\hline Other (specify): & & & & & \\
\hline
\end{tabular}

\section{PART 3: Transferring to our university}

16. Please indicate whether or not you did these things at your 2-Year College prior to transferring to our university?

\begin{tabular}{|c|c|c|}
\hline Statement & Yes & No \\
\hline $\begin{array}{l}\text { I talked with an academic advisor/counselor at my } 2 \text {-Year College about courses I needed } \\
\text { to transfer to our university. }\end{array}$ & & \\
\hline I got information about financial aid available at our university from my 2-Year College. & & \\
\hline $\begin{array}{l}\text { I participated in Transfer Information session presented by our university personnel at my } \\
2 \text {-Year College. }\end{array}$ & & \\
\hline $\begin{array}{l}\text { I talked with an academic advisor/counselor at our university about courses I needed to } \\
\text { transfer to our university. }\end{array}$ & & \\
\hline I got information about financial aid at our university from our university personnel. & & \\
\hline I stayed overnight on the our university campus before applying to our university. & & \\
\hline I participated in an Open House event on our university campus. & & \\
\hline
\end{tabular}

17. How would you rate your 2-Year College with respect to each of the following aspects of your transfer experience?:

Scale 0 to $4\{0=$ Don't know; $1=$ Needs much improvement; $2=$ Needs some improvement; $3=$ Satisfactory; 4 = Outstanding $\}$

a. Availability of good information about transfer requirements

b. Availability of advising and counselling about the transfer requirements

c. Availability of advising and counseling about the transfer process

d. Ease of completing transfer documents

e. Assistance in filling out our university admission application

f. Assistance in providing supporting documents - transcripts, letters of recommendation etc.

g. Timeliness in providing supporting documents for our university admission application

h. Assistance in planning your 2-Year College course work to transfer to our university

18. Other than our university, were you offered admission to any other 4-Year College or University?

Yes / No.

19. How would you rate our university with respect to each of the following aspects of your transfer application process?

Scale 0 to $4\{0=$ Don't know; $1=$ Needs much improvement; $2=$ Needs some improvement; $3=$ Satisfactory; 4 = Outstanding $\}$

- Availability of good information about transfer requirements

- Availability of advising and counselling about the transfer requirements

- Availability of advising and counseling about the transfer process

- Ease of completing transfer documents

- Assistance in filling out our university admission application

- Timeliness in informing you about your admission to our university

○ Timeliness in informing you about the academic credits transferred to our university 
- Access to an Academic Advisor in your major at our university

20. How would you rate our university with respect to each of the following aspects of your financial aid application process?

Scale 0 to 4 \{ $0=$ Don't know; $1=$ Needs much improvement; $2=$ Needs some improvement; $3=$ Satisfactory; 4 = Outstanding $\}$

a. Availability of good information about financial aid available

b. Communication with the Office of Financial Aid and Scholarships

c. Timeliness in informing you about your financial aid package

d. Level of financial aid offered by our university

\section{PART 4: Enrolling at our university}

21. What were your main reasons in enrolling at our university? (Check all that apply)

$\circ$ our university offered the major I was interested in.

o our university is close to my home.

$\circ$ our university provides student housing.

o our university provided me an attractive financial aid package.

o our university has a mandatory co-op program.

○ our university accepted all or most of 2-Year College courses for transfer credit.

- I have lots of friends who attend our university

o our university has a great reputation.

$\circ$ Other (specify):

22. Did you attend any of the Transfer Orientation events in the week of August 21, 2017?

$$
\text { Yes / No }
$$

23. If you attended one or more of the Transfer Orientation events, was any one event useful? Yes / No / Not Applicable

24. Did you attend the Transfer Advising session at our university on August 24, 2017 ? Yes / No

25. If you attended the Transfer Advising session at our university on August 24, was it useful? Yes / No / Not Applicable

26.. How many hours per week do you expect to work on a job for pay?

$$
0,<5,<10,<15,<20,>20
$$

27. To what extent do you expect each of these be a challenge in meeting your academic and career goals at our university?

\begin{tabular}{|l|l|l|l|l|}
\hline \multirow{2}{*}{ Challenge } & \multicolumn{3}{l|}{ To what degree is this a challenge? } \\
\cline { 2 - 5 } & $\begin{array}{l}\text { A great } \\
\text { deal }\end{array}$ & Some & Not much & Not at all \\
\hline Personal Issues & & & \\
\hline Family & & & \\
\hline Roommates & & & & \\
\hline Physical health concerns & & & \\
\hline Mental/emotional health concerns & & & \\
\hline Homesickness & & & & \\
\hline Adjustment to college life & & & \\
\hline Personal safety on and around campus & & & \\
\hline $\begin{array}{l}\text { Other personal concerns (please } \\
\text { specify): }\end{array}$ & & & \\
\hline Resource Issues & & & \\
\hline
\end{tabular}




\begin{tabular}{|l|l|l|l|l|}
\hline Difficulty finding a job & & & \\
\hline General stress balancing classes \& work & & & & \\
\hline Paying for tuition, books, and supplies & & & & \\
\hline Finding affordable housing & & & & \\
\hline Finding reliable transportation & & & \\
\hline $\begin{array}{l}\text { Other financial concerns (please } \\
\text { specify): }\end{array}$ & & & & \\
\hline Academic Issues & & & & \\
\hline Papers, class projects, and/or exams & & & \\
\hline Keeping up with reading & & & \\
\hline Keeping up with the work & & & \\
\hline Motivation/staying focused & & & \\
\hline Learning disabilities & & & \\
\hline Academic advising & & & \\
\hline Career and/or Co-op advising & & & \\
\hline Faculty attitudes and support & & & \\
\hline Faculty approachability/accessibility & & & \\
\hline $\begin{array}{l}\text { Other academic concerns (please } \\
\text { specify): }\end{array}$ & & & & \\
\hline Social Issues & & & \\
\hline Maintaining a work/play balance & & & \\
\hline Campus activities and/or clubs & & & \\
\hline Finding the kinds of friends I want & & & \\
\hline Feeling like I “fit in" & & & \\
\hline
\end{tabular}

28. In the space below, please comment on any experiences you have had so far related to your transfer to our university:

\begin{tabular}{|l|l|}
\hline \\
\hline
\end{tabular}

29. Are you willing to participate in a student focus group ( 30 minutes to 1 hour) to discuss your transfer experiences?

Yes

No

If yes, please provide your e-mail to contact:

\section{End of the Survey}

Acknowledgement: Questions included in this survey are adapted from the instruments reported in the following:

Burack, C., Lanspery, S., Shields, T. P., \& Singleton, S. (2014). Partnerships that promote success: Lessons and findings from the evaluation of the Jack Kent Cook Foundation's community college transfer initiative. Waltham, MA: The Center for Youth and Communities, Brandeis University.

Laanan, F. S. (1998). Beyond transfer shock: A study of students' college experiences and adjustment processes at UCLA (Doctoral dissertation, University of California, Los Angeles).

Peddle, M. T., \& Trott, C. E. (nd). Transfer student satisfaction survey. Illinois Board of Higher Education. Wang, X. (2016). Upward Transfer in STEM Fields of Study: A New Conceptual Framework and Survey Instrument for Institutional Research. New Directions for Institutional Research, 2016(170), 49-60. 